\title{
Accountants' IT Competencies and IT Responsibilities in Supporting IT Sustainability Practice: The Variations of Students' Perspective
}

\author{
Hendri Kwistianus ${ }^{1 *}$, Saarce Elsye Hatane ${ }^{2}$, \\ Melissa Wong ${ }^{3}$, Eden Victoria ${ }^{4}$, Angela Irena Gunawan ${ }^{5}$ \\ 1,2,3,4,5 Faculty of Business and Economics, Petra Christian University \\ J1. Siwalankerto 121-131, Surabaya 60236, Indonesia \\ *Corresponding author, Email: Hendri.kwistianus@petra.ac.id
}

\begin{abstract}
This study looks at the variability of accounting students' perceptions in Indonesia on the importance of IT competence and IT responsibility for accountants and the importance of IT sustainability practices. This study measures different perceptions of accounting students based on gender (male and female), year of study (junior and senior), and the type of university (public and private). The majority of accounting students agree with the importance of accountants' role in IT sustainability practices by utilizing information systems. However, differences in perceptions of accountants' IT responsibility, accountants' IT competence, and the importance of IT sustainability practice are found in the senior and junior student groups. This finding results in junior students being higher than senior students in understanding the importance of the accountants' role in the IT sustainability practice. Differences were also found in the groups of students from public and private universities, where students in public universities have a higher perception than students in private universities toward IT sustainability issues. There is no difference in perception in the gender group. This study can be helpful for higher education providers and teachers in accounting who play an essential role in supporting students to understand the practical implementation in accounting professions regarding their role in sustainability through the utilization of information technology.
\end{abstract}

Keywords: IT Sustainability Practice; Information System Technology; Accountants' IT Responsibilities; Accountants' IT Competencies; Students' Perception.

\section{Introduction}

The rapid development of information technology affects the business world and other fields, such as health, education, government, and others. Accountants are a profession that has developed from century to century and has experienced ups and downs in maintaining its existence (Rosmida, 2019). The competence of an accountant must keep developing along with the increasing utilization of information technology that enables businesses to capture an enormous amount of data. The use of information technology is intended to facilitate data processing and storage of data (Soetanto et al., 2020). The main goal is to make work easier, save costs, improve supervision, and increase productivity so that companies can maximize their profits (Junger da Silva et al., 2020a; Jiputra et al., 2020). Technological advances can help accountants' work to organize, process, and analyze data faster so they can save costs and Time (Kruskopf et al., 2020). In addition, computers can automate making financial reports in real-time.

From a business perspective, the term Information Technology is related to any system for retrieving, collecting, processing, storing, and transmitting data, usually also known as Information Systems (IS). Over the past decade, IT has modified how data is collected, stored, processed, and distributed among business stakeholders (Dimitrios et al., 2013). Accountants are among the professionals affected by this change, as IT has become an essential part of their profession. Therefore, the international education accrediting agency used by the world's top universities, the Association to Advance Collegiate Schools of Business (AACSB), makes a standard that accountants need to have information technology skills and knowledge (AACSB International, 2014). These standards focus on accounting education providers should include learning experiences that develop skills and knowledge related to the integration of information technology in accounting and business. It includes data creation, sharing, analytics, data mining, reporting, and storage (Andiola et al., 2020).

Electronic data processing has replaced paper-based transaction recording in many parts of the world, making it more efficient and minimizing paper usage. However, the rapid utilization of information technology can also generate other 
negative impacts to the environ-ment, such as the high usage of electrical energy and electronic waste that is difficult to decompose and contains toxic materials that lead to severe human and environmental problems (Kiddee et al., 2013). IT sustainability practice is a develop-mental technology concept based on environ-mentally friendly and energy efficiency. IT sustainability practices include planning to buy environmentally friendly IT equipment, lower power consumption, recycling IT equipment, and an environmentfriendly way of disposing of IT equipment (B ose \& Luo, 2011, 2012). From an accounting perspective, accountants can directly contribute to IT sustainability by understanding asset management, continuous energy consumption monitoring to achieve energy efficiency, and providing environmental reports as a management control system (Junger da Silva et al., 2020b).

Universities have an essential role in social change, so sustainable technology can be planted since student age. Thus, accounting students need to understand their role, as future accountants, in supporting sustainability through the utilization of information system technology. However, research is still rare on how accounting students understand information system technology in sustainability. Accounting students will hold important role as professional accountants in society (Tandiontong et al., 2019); hence accounting education providers should equip students with sufficient and relevant competencies. Higher education providers in accounting should analyze society's graduate profile and competencies to face an ever-changing business environment. Accounting program study graduate profile is an outcome on how the accounting education was implemented. Hence it is important to update the curriculum to be in accordance with the graduate profile (Parawiyati et al., 2014). Therefore, this study aims to measure the perception of accounting students in Indonesia about how important IT competence and IT responsibility for accountant, and their role as future accountant professionals in IT sustainability practice. This study also has important implications for higher education providers and teachers in accounting who play an essential role in assisting accounting students in understanding accountants' role in information technology sustainability.

\section{Literature review}

\subsection{IT Competence and Accounting}

IT competence in accounting studies has been discussed many decades since the computer era emerged. In the early stages of IT utilization in business, the IT competencies required by accountants relate to the ability to use specific software packages and the essential requirement of the business. In the 90s, accountants' IT competencies emerged toward information systems such as accounting information systems and management information systems. IT skills required for graduate accountants are defined as spreadsheets, database management systems, system development, accounting systems, and telecommunications. In the internet era, significant changes are in the importance of telecommunications and network competencies. Accountants must know how to transfer files, upload and download data, use local area networks, electronic commerce, the world wide web, and others. Programming competence seems to have decreased, but system development competence has emerged. In the 2000s era, the requirements for IT competencies were shifted from a technological view to a more business view (Damasiotis et al., 2015; Soetanto et al., 2020). Many research strengthen the need for accountants to broaden their IT competence on audit automation skills (Brennan et al., 2017; Ernst \& Young, 2016; Kokina \& Davenport, 2017; Tandiontong et al., 2019), understanding IT governance and IT strategy (Damasiotis et al., 2015), and big data analytics skills (Sledgianowski et al., 2017; Richardson \& Shan, 2019; Dzuranin et al., 2018; Andiola et al., 2020; Jiputra et al., 2020).

It can be concluded that IT has become an essential part of the accounting profession. Accountants in this era are expected to have a hybrid of IT, accounting, and business strategy knowledge and skills. Therefore, in the education context, there are more demands for the needs of accounting graduates to have adequate IT-related skills. Accounting students need to equip themselves to resist the threat of automation to the accounting profession, and data analytics knowledge and skills increase students' competitiveness in the job market (Richardson \& Shan, 2019). Association to Advance Collegiate Schools 
of Business (AACSB), as a well-known business school accreditation, stated in its standard for accounting academic institution accreditation, the accounting degree programs need to integrate ITrelated components within the curriculum, for example data creation/manipulation/management, security, and storage, data analytics, and technology agility (AACSB International, 2018). United Nations Conference on Trade and Development (UNCTAD) also created a benchmark curriculum to describe the technical subject areas that an individual must master to become a professional accountant. This curriculum was formulated with certified professional accountants, the International Federation of Accountants, and academicians worldwide. UNCTAD curriculum also specifies information technology knowledge and skills for accounting students, for example, system concept and management, IT infrastructure, interaction with IT staff, strategic decision about IT, data organization, internal control in IT-based business, and IT security (UNCTAD, 2011).

This study distinguished between accountants' IT competence and accountants' IT responsibility. IT responsibility refers to accountants' role or function concerning IT, while IT competence refers to knowledge and specific skills needed for accountants to perform in the roles and functions related to IT. The indicators for IT competence and IT responsibility are adopted from Model Accounting Curriculum (UNCTAD, 2011).

\subsection{Accounting and Sustainability Issue}

The accounting discipline is never a stranger to the sustainability issue. For example, it is shown that social and environmental topics in accounting research can be drawn back to since the 1990s. The number of research specified on this topic in critical perspectives on accounting journal was started from only around 15 research published in the 1990s to 24 research in only five years between 2009 - 2014 (Deegan, 2017). In the last five years, there is more research related to sustainability issues from research on corporate social responsibility (Khan et al., 2020; She \& Michelon, 2019), sustainability, and integrated reporting (Bebbington et al., 2020; de Villiers \& Sharma, 2020; Journeault et al., 2021), and sustainability issue related to the covid pandemic situation (Adams \& Abhayawansa, 2021; Cho et al., 2021). There is also an increasing trend in sustainability reporting worldwide, where accountants play an important role both as preparers or as auditors of the report (Tandiontong et al., 2019). The KPMG survey of sustainability reporting has found that 80 percent of the companies worldwide now report on sustain-ability, and the figure rise over 90 percent among the largest companies in the world (KPMG, 2020). In Asia Pacific, sustainability reporting has grown by six percentage points since 2017 to 84 percent. This surge due to some countries in the region are among the global leaders, including Japan (100 percent), Malaysia (99 percent), India (98 percent), Taiwan (93 percent) and Australia (92 percent).

Accounting contributes to sustainability reporting due to the sustainability accounting concept, also known as environmental accounting. Environmental accounting includes a set of activities that increase the power of accounting systems to identify, record, and report the effects of environmental degradation and pollution. It provides information that helps managers evaluate, operate, control, decide, report, and protect the environment (Rounaghi, 2019). Accountants play a pivotal role in sustainable development as they measure, evaluate and disclose the progress made by companies in achieving sustainability (Makarenko \& Plastun, 2017). To assist accountants in sustainability reporting and its complexity, integration with information systems and technology would be helpful. Much data and information must be managed from business activities and their impact on the environment to provide quality sustainability reporting. $\mathrm{O}$ of the tools necessary for carbon accounting is a quality information system (Merhout et al., 2016).

Accounting education providers are responsible for graduating future professional accountants who will play an essential role in companies' decision-making and strategy development process, including strategic issues related to sustainability (Boulianne et al., 2018). Higher education should develop its students' values, knowledge, and understanding, including sustainable development issues into its curriculum (Ebaid, 2021). In that way, higher education plays an important role that will help to shape the views of future citizens, leaders, and policymakers. One of the United Nations (UN) sustainable development goals is to ensure that all students acquire the knowledge and skills necessary to promote sustainable development (UNESCO, 2017). Therefore, accounting graduates also need to have the skills, knowledge, values, and competencies to deal with sustainable development goals. Hence, it is crucial to develop accounting education to 
integrate sustainability issues. However, integrating sustainability in accounting education is about exposing students with information related to sustainability and encouraging students to engage in learning activities that will enable them to practice critical thinking toward environmental and sustainability issues (Ceulemans et al., 2015). It also requires management commitment to integrate hands-on practices on campus (Müller-Christ et al., 2014) and problem-based learning (Wyness \& Dalton, 2018) to help improve students' understanding of sustainability issues.

\subsection{IT Sustainability Practice and Accounting}

The focus of sustainable information techno$\operatorname{logy}$ is to reduce the energy costs of IT operations and the negative impacts to the environment from the rapid utilization of information technology. The environmental impacts of IT utilization, such as high volume of energy consumption, raise a major concern for the industry either from an environmental or economic perspective and electronic waste. Kiddee et al. (2013) display in their study two ways of how electronic waste disposals may impact human health, contamination of toxic substances in the food chain and direct impact on labor in recycling areas due to exposure to toxic substances. It is supported by Rene et al. (2021) which highlight the need for a proper recycling system of electronic waste because of the inappropriate disposal practices that cause severe environmental pollution and health hazards.

Sustainable information technology practice will integrate the IT role of the organization's business with global sustainability and social responsibility (Vicente-Molina et al., 2018). It refers to aligning an organization's IT strategies with social responsibility to encourage IT governance and management behaviour changesoward more environmentally friendly IT practices (Harmon et al., 2012). The practices include planning of buying environmentally friendly IT equipment, lower power consumptions, recycling IT equipment, and environmentfriendly way of disposing of IT equipment (Bose \& Luo, 2011, 2012).

Both company and customer may gain benefit from IT sustainability practices. Benefits for the company such as cost reductions as a consequence of more efficient and strategy-related IT usage. Customers and society may benefit from higher satisfaction of the company products or services due to less negative environmental im- pacts that lead to higher credibility and trust of the company's products or services (Harmon et al., 2012). Accounting may take part in IT sustainability practice by creating, monitoring, and evaluating environmental indicators and supported by applying an environmental management information system (EMIS). EMIS may help an organization automate ecological management activities, incorporate lifecycle assessments and environmental cost accounting, and meet compliance reporting requirements. This will allow organizations to successfully manage their carbon footprint and the complexity of carbon accounting and reporting.

This study aims to measure differences in perceptions of accountants' IT responsibility, accountants' IT competence, and the importance of IT sustainability practice of accounting students based on gender (male and female), year of study (junior and senior), and the type of university (public and private). Some previous studies have shown differences in perception from gender (Xiao \& Hong, 2018; Olsson et al., 2019), year of study and type of university (Wang et al., 2020) toward sustainability issues. Research questions and Conceptual Model are structured as follows:

RQ1. What is accounting students' perception on the importance of IT sustainability practice, accountants' IT responsibility, and accountants' IT competence?

RQ2. Is there a different perception of accounting students in the gender, year of study, and university type group on accountants' responsibilities in the use of IS technology?

RQ3. Is there a different perception of accounting students in the gender, year of study, and university type group on accountants' competence in the use of IS technology?

RQ4. Is there a different perception of accounting students in the gender, year of study, and university type group on accountants' role in IT sustainability practice?

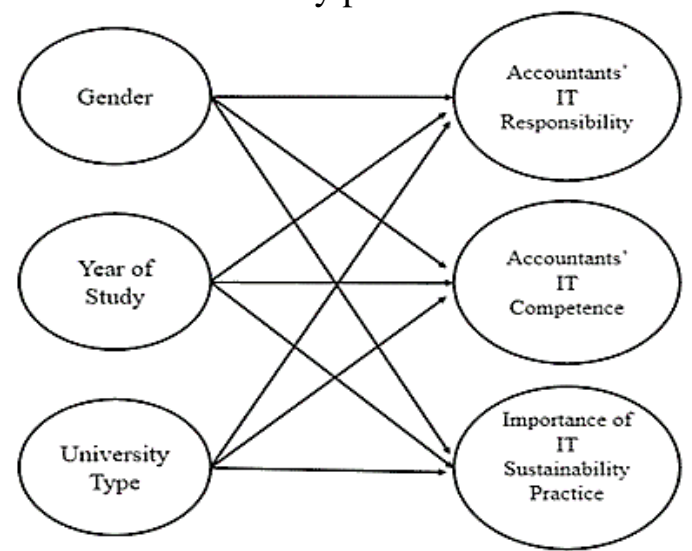

Figure 1. Conceptual Model 


\section{Methods}

Table 1. Identification of Accountants' IT Competencies, Accountants' IT Responsibilities and IT Sustainability Practice

\begin{tabular}{|c|c|c|c|c|c|}
\hline & Competencies & & Responsibilities & & IT Sustainability Practice \\
\hline COMP1 & $\begin{array}{l}\text { Understand about IT, and the } \\
\text { scope of work of the IT } \\
\text { department }\end{array}$ & RESP1 & $\begin{array}{l}\text { Accountants play a role in } \\
\text { departments related to IT }\end{array}$ & SUST1 & $\begin{array}{l}\text { Contract clean/renewable } \\
\text { energy }\end{array}$ \\
\hline COMP2 & $\begin{array}{l}\text { Understand their role in IT } \\
\text { infrastructure decisions }\end{array}$ & RESP2 & $\begin{array}{l}\text { Have skills related to IT to } \\
\text { maximize their professional } \\
\text { role }\end{array}$ & SUST2 & Optimize DC cooling \\
\hline COMP3 & $\begin{array}{l}\text { Understand the importance to } \\
\text { interact with IT functions }\end{array}$ & RESP3 & $\begin{array}{l}\text { Involved in strategic decision } \\
\text { making, such as allocating } \\
\text { Hardware and software }\end{array}$ & SUST3 & Adopt parallel computing \\
\hline COMP4 & $\begin{array}{l}\text { Understand large-scale } \\
\text { systems }\end{array}$ & RESP4 & $\begin{array}{l}\text { Involved in IT infrastructure } \\
\text { decision making }\end{array}$ & SUST4 & $\begin{array}{l}\text { Manage IT equipment life } \\
\text { cycle }\end{array}$ \\
\hline COMP5 & $\begin{array}{l}\text { Understand their role in IT } \\
\text { decision-making processes }\end{array}$ & RESP5 & $\begin{array}{l}\text { Involved in decision making } \\
\text { to make or purchase hardware } \\
\text { and software }\end{array}$ & SUST5 & Sustainable IT procurement \\
\hline COMP6 & $\begin{array}{l}\text { Apply data analyst techniques, } \\
\text { design, and develop a system } \\
\text { in IT }\end{array}$ & RESP6 & $\begin{array}{l}\text { Involved in decision making } \\
\text { to outsource or insourcing }\end{array}$ & SUST6 & E-waste management \\
\hline COMP7 & $\begin{array}{l}\text { Discuss procedures to allow } \\
\text { system maintenance to be } \\
\text { carried out accurately and in a } \\
\text { timely manner }\end{array}$ & RESP7 & $\begin{array}{l}\text { Involved in decision making } \\
\text { to automate business functions }\end{array}$ & SUST7 & $\begin{array}{l}\text { Virtualize servers \& data } \\
\text { storage devices }\end{array}$ \\
\hline COMP8 & $\begin{array}{l}\text { Understand the cycle of } \\
\text { upgrading and replacing IT } \\
\text { equipment }\end{array}$ & RESP8 & $\begin{array}{l}\text { Involved in supporting } \\
\text { business processes and } \\
\text { organizational strategies in the } \\
\text { field of IT }\end{array}$ & SUST8 & Migrate to cloud computing \\
\hline COMP9 & $\begin{array}{l}\text { Understand existing resource } \\
\text { management issues }\end{array}$ & RESP9 & $\begin{array}{l}\text { Involved in making decisions } \\
\text { to adopt new technologies }\end{array}$ & SUST9 & $\begin{array}{l}\text { Monitor energy consumption } \\
\& \text { emission }\end{array}$ \\
\hline COMP10 & $\begin{array}{l}\text { Understand the importance of } \\
\text { electronic commerce in } \\
\text { today's business environment, } \\
\text { how it works, what the costs } \\
\text { are and what changes are } \\
\text { incurred for the company }\end{array}$ & RESP10 & $\begin{array}{l}\text { Involved in assisting in } \\
\text { making decisions about the } \\
\text { use of IT strategies }\end{array}$ & SUST10 & $\begin{array}{l}\text { Manage IT performance } \\
\text { indicators }\end{array}$ \\
\hline COMP11 & $\begin{array}{l}\text { Understand the implications } \\
\text { of equipment configuration } \\
\text { changes and software } \\
\text { configurations }\end{array}$ & & & SUST11 & $\begin{array}{l}\text { Report IT environmental } \\
\text { performance to external }\end{array}$ \\
\hline
\end{tabular}

Data was collected using a questionnaire adapted from Junger da Silva et al. (2020a) that identified accountants' IT responsibilities and competencies indicators (UNCTAD, 2011). In addition, a questionnaire for IT sustainability practice was adopted from (Junger da Silva et al., 2020b). It summarizes 11 indicators for IT sustainability practice from previous studies based on three categories, namely green data center, green cloud computing, and environmental management information system (EMIS). The questionnaires were reformulated to students' context for understandability. All variables identification is detailed in Table 1 .

The perception of the students was measured using a Likert scale of 1-5. Questionnaires were distributed to active students majoring in accounting using purposive sampling. Accounting students were chosen as unit analysis because they will hold an important role as professional accountants in society. Hence accounting education providers should equip students with sufficient and relevant IT competencies. Respondents ages range from 18 to 22 years old from public and private universities in Indonesia. The number of answers studied was 387 respondents from university students in Indonesia. The selection of the universities is both from private and public universities that have an accounting study program.

Table 2. Respondent Profile

\begin{tabular}{llrr}
\hline & Profile & Frequency & Percent \\
\hline \multirow{2}{*}{ Gender } & Male & 99 & $26 \%$ \\
& Female & 288 & $74 \%$ \\
& Total & 387 & $100 \%$ \\
\hline Year of & $1^{\text {st }} \& 2^{\text {nd }}$ Year & 185 & $48 \%$ \\
Study & $3^{\text {rd }}$ Year \& Beyond & 202 & $52 \%$ \\
& Total & 387 & $100 \%$ \\
\hline University & Public University & 140 & $36 \%$ \\
Type & Private University & 247 & $64 \%$ \\
& Total & 387 & $100 \%$ \\
\hline
\end{tabular}

Table 2 summarizes the respondent profiles from 387 valid answers. The gender profile consists of $26 \%$ male and $74 \%$ female, year of 
study profile comprised of $48 \%$ respondents were first. The second-year that is junior students and $52 \%$ of respondents were the third years and beyond that is senior students. The university type profile consists of $36 \%$ respondents from public university and $64 \%$ from a private university.

Data analysis consisted of normality test, validity test, reliability test. In addition, the MannWhitney u-test and Kruskal Wallis test was also used to determine differences between male and female respondents. Also, private university and public university respondents, and year of study in their perception regarding the importance of accountants' IT competencies and accountants' IT responsibilities in supporting IT sustainability.

\section{Results}

The respondents' result was first verified for reliability based on Cronbach's alpha coefficient. The first result about respondents' perception of accountants' IT competencies shows Cronbach's alpha of 0.883 . The second result about respondents' perception of accountants' IT responsibilities shows Cronbach's alpha is 0.890 . Lastly, the respondents' perception of the importance of IT sustainability practice shows Cronbach's alpha is 0.943 . The Cronbach's alpha for all the three groups shows results bigger than 0.6. Therefore, the research items used for the questionnaire can be concluded as reliable.

Regarding the analysis of respondents' perception of the three variables, a category table needs to be set to interpret respondents' answers into the importance perception as in Table 3 . The category table shows how the respondents' answers should be interpreted from unimportant to critical. For example, the answer should be interpreted as very important if the mean falls between 4.20 and 5.00, necessary if the mean falls between 3.40 and 4.19 , and so on. The class interval for each category in the category table was calculated using the difference between the highest and lowest answer value and then divided by the number of answer scales.

Table 3. Indicator Category

\begin{tabular}{cl}
\hline Interval & \multicolumn{1}{c}{ Category } \\
\hline $4.19>$ mean $\leq 5.00$ & Very Important \\
$3.39>$ mean $\leq 4.19$ & Important \\
$2.29>$ mean $\leq 3.39$ & Neutral \\
$1.79>$ mean $\leq 2.59$ & Not Important. \\
$1.00>$ mean $\leq 1.79$ & Very Unimportant \\
\hline
\end{tabular}

Analysis for respondents' perception of accountants' IT competence shows an overall mean of 4.21 , which fall into the very important category, showing that students perceived IT competencies as an essential skill for accountants. Item COMP2 related to "Accountant needs to understand their role in IT infrastructure decisions" shows the highest result followed by item COMP1 related to "Accountant needs to understand about IT, and the scope of work of the IT department" with mean results 4.67 and 4.4 respectively as in Table 4 . These results indicate that students viewed IT-related skills are very important skills for accountants. A solid understanding of IT and what the IT people do can be a good foundation for accountants to interact with the IT functional areas to contribute more to the strategic decision-making regarding IT infrastructure.

Table 4. Respondents' Perception of Accountants' IT Competencies

\begin{tabular}{|c|c|c|}
\hline \multicolumn{3}{|c|}{ IT Competence } \\
\hline & Item & Mean \\
\hline COMP1 & $\begin{array}{l}\text { Understand about IT, and the scope } \\
\text { of work of the IT department }\end{array}$ & 4.40 \\
\hline COMP2 & $\begin{array}{l}\text { Understand their role in IT } \\
\text { infrastructure decisions }\end{array}$ & 4.67 \\
\hline COMP3 & $\begin{array}{l}\text { Undertand the importance to } \\
\text { interact with IT functions }\end{array}$ & 4.21 \\
\hline COMP4 & Understand large-scale systems & 3.97 \\
\hline COMP5 & $\begin{array}{l}\text { Understand their role in IT decision- } \\
\text { making processes }\end{array}$ & 3.82 \\
\hline COMP6 & $\begin{array}{l}\text { Apply data analyst techniques, } \\
\text { design, and develop a system in IT }\end{array}$ & 4.12 \\
\hline COMP7 & $\begin{array}{l}\text { Discuss procedures on system } \\
\text { maintenance }\end{array}$ & 4.33 \\
\hline COMP8 & $\begin{array}{l}\text { Understand the cycle of upgrading } \\
\text { and replacing IT equipment }\end{array}$ & 4.26 \\
\hline COMP9 & $\begin{array}{l}\text { Understand existing resource } \\
\text { management issues }\end{array}$ & 4.07 \\
\hline COMP10 & $\begin{array}{l}\text { Understand the importance of e- } \\
\text { commerce in today's business }\end{array}$ & 4.25 \\
\hline COMP11 & $\begin{array}{l}\text { Understand the implications of } \\
\text { equipment and software } \\
\text { configurations }\end{array}$ & 4.17 \\
\hline Category & & 4.21 \\
\hline
\end{tabular}

Analysis for respondents' perception of accoutants' IT responsibilities shows overall mean 4.20 , which fall into the very important category, showing that students perceived accountant plays a very important role in IT and needs to be involved in IT-related strategic decision making. Item RESP4 related to "Accountant needs to be involved in IT infrastructure decision making" shows the highest result followed by item RESP3 related to "Accountant needs to be involved in strategic decision making, such as allocating hardware and software resources" with mean result 4.51 and 4.36 respectively as shown in Table 5. These results indicate that students 
viewed accountant as a very important role to be involved in IT decision making, especially related to IT infrastructure. Decision making in IT infrastructure including make or buy, outsourcing or insourcing, adopt new technology, and disposal of hardware and software. This finding is in contrast with previous study that found strong disagree for accountants to participate in highly technical issues, such as IT infrastructure decisions, as it is not perceived as a primary function of accountants (Junger da Silva et al., 2020a).

Table 5. Respondents' Perception of Accountants' IT Responsibilities

\begin{tabular}{|c|c|c|}
\hline \multicolumn{3}{|c|}{ IT Responsibility } \\
\hline & Item & Mean \\
\hline RESP 1 & $\begin{array}{l}\text { Accountants play a role in } \\
\text { departments related to IT }\end{array}$ & 4.27 \\
\hline RESP 2 & $\begin{array}{l}\text { Have skills related to IT to } \\
\text { maximize their professional role }\end{array}$ & 4.22 \\
\hline RESP 3 & $\begin{array}{l}\text { Involved in strategic decision } \\
\text { making }\end{array}$ & 4.36 \\
\hline RESP 4 & $\begin{array}{l}\text { Involved in IT infrastructure } \\
\text { decision making }\end{array}$ & 4.51 \\
\hline RESP 5 & $\begin{array}{l}\text { Involved in decision making to } \\
\text { make or purchase hardware and } \\
\text { software }\end{array}$ & 4.18 \\
\hline RESP 6 & $\begin{array}{l}\text { Involved in decision making to } \\
\text { outsource or insourcing }\end{array}$ & 4.18 \\
\hline RESP 7 & $\begin{array}{l}\text { Involved in decision making to } \\
\text { automate business functions }\end{array}$ & 4.01 \\
\hline RESP 8 & $\begin{array}{l}\text { Involves in supporting business } \\
\text { processes and strategies in IT }\end{array}$ & 4.04 \\
\hline RESP 9 & $\begin{array}{l}\text { Involved in making decisions to } \\
\text { adopt new technologies }\end{array}$ & 4.25 \\
\hline RESP 10 & $\begin{array}{l}\text { Involved in assisting in making } \\
\text { decisions about the use of IT } \\
\text { strategies }\end{array}$ & 4.02 \\
\hline Category & & 4.20 \\
\hline
\end{tabular}

The importance of IT sustainability practice for accountant in students' perspective shows overall mean 3.98 which fall into the important category. This result showing that students perceived it is important for accountant to understand IT sustainability practices. Item SUST10 related to "Accountants need to manage IT performance indicators" shows the highest result, followed by item SUST11 related to "Accountant needs to report IT environmental performance to external" with mean results 4.09 and 4.06 respectively as in Table 6 . These results indicate that students viewed it is important for accountant to understand and contribute to IT sustainability practice related to manage IT performance indicators and IT environmental reporting. Accounting education is closely related to performance indicators and environmental reporting. Thus it can be said that accounting students value most of the IT sustainability practice items that are familiar to them.

Table 6. Respondents' Perception of The Importance of IT Sustainability Practice

\begin{tabular}{llc}
\hline \multicolumn{2}{c}{ IT Competence } \\
\hline \multicolumn{1}{c}{ Item } & Mean \\
\hline SUST1 & Contract clean/renewable energy & 4.02 \\
SUST2 & Optimize DC cooling & 3.84 \\
SUST3 & Adopt parallel computing & 4.01 \\
SUST4 & Manage IT equipment life cycle & 3.96 \\
SUST5 & Sustainable IT procurement & 4.01 \\
SUST6 & E-waste management & 3.74 \\
SUST7 & Virtualize servers \& data storage & 3.98 \\
& devices & 4.14 \\
SUST8 & Migrate to cloud computing & 3.93 \\
SUST9 & Monitor energy consumption \& \\
& emission & 4.09 \\
SUST10 & Manage IT performance indicators & 4.06 \\
SUST11 & Report IT environmental & 3.98 \\
\hline Category & & \\
\hline
\end{tabular}

Regarding the analysis for lowest value items in each variable, accountants' IT competencies item COMP5 "Accountant needs to understand their role in IT decision-making processes" and COMP4 "Accountant needs to understand largescale systems" show lowest result with 3.82 and 3.97 respectively. Accountants' IT responsibilities item RESP7 "Accountant needs to be involved in decision making to automate business functions" and RESP10 "Accountant needs to be involved in assisting in making decisions about the use of IT strategies" show lowest result with 4.01 and 4.02 respectively. IT sustainability practice item SUST6 "Accountants need to understand how to manage electronic waste properly and correctly" and SUST2 "Accountants need to understand how to optimize data center cooling" show lowest result with 3.74 and 3.84 respectively. A possible explanation for these results is that concepts about large-scale systems, decision making in IT, electronic waste, and data center cooling are still too vague for students. This can be compared with the highest value items, wherein COMP2, RESP4, and RESP3 the decision making is specified for IT infrastructure and in SUST10 and SUST11, the IT sustainability practice is related to familiar terms such as performance indicators and environmental reporting. However, since these results still fall in the important category, students are open to understanding the concept of large-scale systems, IT decision making, electronic waste, and data center cooling. 
Table 7. Mann-Whitney U Test Result for Gender, Year of Study, and University Type Group on Accountants' IT Competence

\begin{tabular}{|c|c|c|c|c|c|c|c|c|c|c|c|c|c|}
\hline \multirow[t]{2}{*}{ Group } & \multirow[t]{2}{*}{ Items } & \multicolumn{2}{|c|}{$\begin{array}{c}\text { Mean Rank } \\
\text { Gender Type }\end{array}$} & \multirow{2}{*}{$\begin{array}{c}\text { Mann- } \\
\text { Whitney } \\
\text { U }\end{array}$} & \multirow{2}{*}{$\begin{array}{l}\text { Asymp } \\
\text { Sig (2- } \\
\text { tailed) }\end{array}$} & \multicolumn{2}{|c|}{$\begin{array}{l}\text { Mean Rank Year } \\
\text { of Study Type }\end{array}$} & \multirow{2}{*}{$\begin{array}{c}\text { Mann- } \\
\text { Whitney } \\
\text { U }\end{array}$} & \multirow{2}{*}{$\begin{array}{l}\text { Asymp } \\
\text { Sig (2- } \\
\text { tailed) }\end{array}$} & \multicolumn{2}{|c|}{$\begin{array}{c}\text { Mean Rank } \\
\text { University Type }\end{array}$} & \multirow{2}{*}{$\begin{array}{c}\text { Mann- } \\
\text { Whitney } \\
\text { U }\end{array}$} & \multirow{2}{*}{$\begin{array}{l}\text { Asymp } \\
\text { Sig (2- } \\
\text { tailed) }\end{array}$} \\
\hline & & Male & Female & & & Junior & Senior & & & Private & Public & & \\
\hline \multirow{11}{*}{$\begin{array}{c}\text { Accoun- } \\
\text { tants' IT } \\
\text { Compe- } \\
\text { tence }\end{array}$} & COMP1 & 184.59 & 197.23 & 13324.5 & 0.281 & 196.90 & 191.34 & 18148.0 & 0.587 & 206.75 & 186.78 & 15505.5 & 0.061 \\
\hline & COMP2 & 195.58 & 193.46 & 14100.0 & 0.834 & 194.93 & 193.15 & 18513.0 & 0.840 & 202.96 & 188.92 & 16036.0 & 0.126 \\
\hline & COMP3 & 199.00 & 192.28 & 13761.0 & 0.579 & 188.18 & 199.33 & 17608.0 & 0.291 & 190.46 & 196.01 & 16794.0 & 0.126 \\
\hline & COMP4 & 194.01 & 194.00 & 14255.5 & 1.000 & 191.68 & 196.13 & 18255.0 & 0.679 & 200.99 & 190.04 & 16312.0 & 0.328 \\
\hline & COMP5 & 186.86 & 196.45 & 13459.5 & 0.443 & 189.09 & 198.49 & 17777.5 & 0.389 & 196.02 & 192.86 & 17007.5 & 0.780 \\
\hline & COMP6 & 186.20 & 196.68 & 13484.0 & 0.391 & 200.57 & 187.99 & 17470.0 & 0.239 & 205.90 & 187.26 & 15624.0 & 0.093 \\
\hline & COMP7 & 181.40 & 198.33 & 13008.5 & 0.153 & 192.35 & 195.51 & 18379.0 & 0.760 & 208.32 & 185.88 & 15285.0 & $\mathbf{0 . 0 3 7}$ \\
\hline & COMP8 & 185.20 & 197.03 & 13384.5 & 0.321 & 194.15 & 193.86 & 18657.5 & 0.978 & 204.80 & 187.88 & 15777.5 & 0.118 \\
\hline & COMP9 & 191.05 & 195.02 & 13963.5 & 0.746 & 189.57 & 198.06 & 17865 & 0.428 & 191.25 & 195.56 & 16904.5 & 0.699 \\
\hline & COMP10 & 191.63 & 194.82 & 14021.0 & 0.791 & 189.07 & 198.51 & 17773.5 & 0.368 & 206.25 & 187.06 & 15575.5 & 0.078 \\
\hline & COMP11 & 192.99 & 194.35 & 14156.5 & 0.912 & 197.62 & 190.68 & 18015.0 & 0.514 & 203.80 & 188.45 & 15918.0 & 0.164 \\
\hline
\end{tabular}

Table 8. Table 8. Mann-Whitney U Test Result for Gender, Year of Study, and University Type Group on Accountants' IT Responsibility

\begin{tabular}{|c|c|c|c|c|c|c|c|c|c|c|c|c|c|}
\hline \multirow{2}{*}{ Group } & \multirow{2}{*}{ Items } & \multicolumn{2}{|c|}{$\begin{array}{c}\text { Mean Rank Gender } \\
\text { Type }\end{array}$} & \multirow{2}{*}{$\begin{array}{c}\text { Mann- } \\
\text { Whitney } \\
\text { U }\end{array}$} & \multirow{2}{*}{$\begin{array}{l}\text { Asymp } \\
\text { Sig (2- } \\
\text { tailed) }\end{array}$} & \multicolumn{2}{|c|}{$\begin{array}{l}\text { Mean Rank Year } \\
\text { of Study Type }\end{array}$} & \multirow{2}{*}{$\begin{array}{c}\text { Mann- } \\
\text { Whitney } \\
\text { U }\end{array}$} & \multirow{2}{*}{$\begin{array}{l}\text { Asymp } \\
\text { Sig (2- } \\
\text { tailed) }\end{array}$} & \multicolumn{2}{|c|}{$\begin{array}{c}\text { Mean Rank } \\
\text { University Type }\end{array}$} & \multirow{2}{*}{$\begin{array}{c}\text { Mann- } \\
\text { Whitney } \\
\text { U }\end{array}$} & \multirow{2}{*}{$\begin{array}{l}\text { Asymp } \\
\text { Sig (2- } \\
\text { tailed) }\end{array}$} \\
\hline & & Male & Female & & & Junior & Senior & & & Private & Public & & \\
\hline \multirow{10}{*}{$\begin{array}{c}\text { Accoun- } \\
\text { tants' IT } \\
\text { Respon- } \\
\text { sibility }\end{array}$} & RESP1 & 189.75 & 195.46 & 13835.5 & 0.633 & 200.25 & 188.27 & 17528.5 & 0.252 & 212.20 & 183.68 & 14741.5 & 0.009 \\
\hline & RESP2 & 191.88 & 194.73 & 14046.0 & 0.814 & 199.44 & 189.02 & 17678.5 & 0.324 & 203.70 & 188.50 & 15932.5 & 0.167 \\
\hline & RESP3 & 188.40 & 195.92 & 13702.0 & 0.524 & 198.72 & 189.68 & 17812.0 & 0.380 & 210.72 & 184.52 & 14949.0 & 0.014 \\
\hline & RESP4 & 195.25 & 193.57 & 14132.0 & 0.882 & 200.18 & 188.34 & 17542.5 & 0.233 & 208.27 & 185.91 & 15292.5 & 0.030 \\
\hline & RESP5 & 198.29 & 192.53 & 13831.5 & 0.635 & 197.47 & 190.82 & 18043.0 & 0.531 & 208.87 & 185.57 & 15208.5 & 0.035 \\
\hline & RESP6 & 181.19 & 198.40 & 12988.0 & 0.157 & 203.81 & 185.02 & 16871.0 & 0.077 & 217.41 & 180.73 & 14013.0 & 0.001 \\
\hline & RESP7 & 200.23 & 191.86 & 13639.5 & 0.498 & 207.48 & 181.66 & 16192.0 & 0.017 & 211.35 & 184.17 & 14861.0 & 0.015 \\
\hline & RESP8 & 200.57 & 191.74 & 13606.0 & 0.473 & 206.79 & 182.28 & 16318.0 & 0.023 & 217.61 & 180.62 & 13984.0 & 0.001 \\
\hline & RESP9 & 191.82 & 194.75 & 14040.5 & 0.808 & 199.77 & 188.72 & 17617.5 & 0.292 & 214.88 & 182.16 & 14366.5 & 0.003 \\
\hline & RESP10 & 202.75 & 190.99 & 13389.5 & 0.341 & 204.16 & 184.70 & 16806.0 & 0.071 & 206.44 & 186.95 & 15549.0 & 0.082 \\
\hline
\end{tabular}

Table 9. Mann-Whitney U Test Result for Gender, Year of Study, and University Type Group on IT Sustainability Practice

\begin{tabular}{|c|c|c|c|c|c|c|c|c|c|c|c|c|c|}
\hline \multirow{2}{*}{ Group } & \multirow{2}{*}{ Items } & \multicolumn{2}{|c|}{$\begin{array}{c}\text { Mean Rank Gender } \\
\text { Type }\end{array}$} & \multirow{2}{*}{$\begin{array}{c}\text { Mann- } \\
\text { Whitney } \\
\text { U }\end{array}$} & \multirow{2}{*}{$\begin{array}{l}\text { Asymp. } \\
\text { Sig. (2- } \\
\text { tailed) }\end{array}$} & \multicolumn{2}{|c|}{$\begin{array}{l}\text { Mean Rank Year } \\
\text { of Study Type }\end{array}$} & \multirow{2}{*}{$\begin{array}{c}\text { Mann- } \\
\text { Whitney } \\
\text { U }\end{array}$} & \multirow{2}{*}{$\begin{array}{l}\text { Asymp. } \\
\text { Sig. (2- } \\
\text { tailed) }\end{array}$} & \multicolumn{2}{|c|}{$\begin{array}{c}\text { Mean Rank } \\
\text { University Type }\end{array}$} & \multirow{2}{*}{$\begin{array}{c}\text { Mann- } \\
\text { Whitney } \\
\text { U }\end{array}$} & \multirow{2}{*}{$\begin{array}{l}\text { Asymp. } \\
\text { Sig. (2- } \\
\text { tailed) }\end{array}$} \\
\hline & & Male & Female & & & Junior & Senior & & & Private & Public & & \\
\hline \multirow{11}{*}{$\begin{array}{c}\text { IT } \\
\text { Sustain- } \\
\text { ability } \\
\text { Practice }\end{array}$} & SUST1 & 192.39 & 194.55 & 14097.00 & 0.5944 & 206.31 & 182.73 & 16407.50 & 0.023 & 180.42 & 217.96 & 13935.50 & 0.001 \\
\hline & SUST2 & 198.45 & 192.47 & 13815.50 & 0.4340 & 208.94 & 180.31 & 15920.50 & 0.007 & 176.62 & 224.66 & 12997.50 & 0.000 \\
\hline & SUST3 & 201.44 & 191.44 & 13519.50 & 0.2861 & 207.87 & 181.30 & 16119.00 & 0.012 & 179.71 & 219.21 & 13760.50 & 0.000 \\
\hline & SUST4 & 197.51 & 192.79 & 13908.50 & 0.4861 & 206.16 & 182.86 & 16434.50 & 0.029 & 180.33 & 218.12 & 13913.50 & 0.001 \\
\hline & SUST5 & 201.84 & 191.30 & 13479.50 & 0.2694 & 206.80 & 182.28 & 16317.50 & 0.022 & 183.24 & 212.98 & 14632.50 & 0.007 \\
\hline & SUST6 & 196.87 & 193.01 & 13972.00 & 0.5243 & 202.39 & 186.32 & 17133.50 & 0.094 & 181.03 & 216.88 & 14087.00 & 0.001 \\
\hline & SUST7 & 198.11 & 192.59 & 13849.50 & 0.4507 & 207.24 & 181.88 & 16236.00 & 0.017 & 181.36 & 216.30 & 14168.50 & 0.002 \\
\hline & SUST8 & 189.24 & 195.64 & 13784.50 & 0.416 & 206.21 & 182.82 & 16426.50 & 0.028 & 180.77 & 217.35 & 14021.00 & 0.001 \\
\hline & SUST9 & 204.61 & 190.35 & 13205.50 & 0.1708 & 203.88 & 184.95 & 16857.00 & 0.078 & 184.62 & 210.55 & 14973.50 & 0.020 \\
\hline & SUST10 & 204.70 & 190.32 & 13197.00 & 0.1625 & 202.21 & 186.49 & 17167.00 & 0.095 & 181.09 & 216.78 & 14101.00 & 0.001 \\
\hline & SUST11 & 206.45 & 189.72 & 13023.00 & 0.1201 & 206.36 & 182.68 & 16398.50 & 0.027 & 187.97 & 204.65 & 15799.50 & 0.093 \\
\hline
\end{tabular}


The non-parametric test, Mann-Whitney utest, shows no significant differences in the gender group for all three dependent variables where there is no p-value under 0,1 for al three variables. The year of study group shows significant differences result between junior and senior students in IT sustainability practice variable and in some items of accountants' IT responsibilities. This is shown with p-value result under 0,1 for RESP6, RESP7, RESP8, RESP10 and for all items in IT sustainability practice variable. The university type group shows significant differences between public and private university students in accountants' IT responsibilities and IT sustainability practice also in some items of accountants' IT competence.

\section{Discussion}

The majority of accounting students agree with the importance of accountants' role in IT sustainability practices by utilizing information systems. Utilizing information systems means that accountants have the competence and realize their role with respect to IT, or in other words accountants' IT competence and IT responsibilities. Students show high perceptions in the need for accountant to understand IT and ITrelated scope of work, to be involved in IT strategic decision, and manange IT and environmental performance. The difference in students' perception regarding the highest and lowest results show that some IT sustainability terms are still unfamiliar for students. Consequently, the recommendation accounting education provider is to design an accounting curriculum that is integrated with IT competencies, accountants' role in IT strategic decision, and introducing more to the students related to their future professional role on IT sustainability issues.

This study is in line with some previous studies that emphasize on the importance of infused IT-related skills in the accounting curriculum. Dzuranin et al. (2018) in their study shows the importance of developing students' data analytics mindset as the most important data analytics topic to include in the accounting curriculum. Data analytics mindset related to datadriven critical thinking skills, which means developing students' ability to ask questions that can be answered using data. Their study also suggests accounting education provider developing students' ability to communicate processes and outcomes of data analytics processing effectively. Andiola et al. (2020) in their study on leaders of AACSB accredited accounting programs, shows results suggest that standard A7 has had a significant impact on promoting change in the accounting curriculum regarding the importance of teaching technology-related skills and data analytics. The study also shows that most of the leading AACSB accredited accounting programs have already implemented the changes in their curriculum despite some challenges to fully implement the change in the curriculum. Finally, Anis (2017) in his study shows an important perspective from professional accountants expectations and accounting students actual skills. The study compares accounting educators' and auditors' perceptions of accounting education gaps and their impact on audit quality in Egypt. The results indicate that accounting educator focuses more on developing accounting knowledge rather than generic skills, despite generic skills, including information technology skill, are significantly and positively responsible for audit quality in the Egyptian auditing market.

Regarding the gender group, it is found that there is no significant difference. It can be interpreted that both male and female students have the same perception about the importance of accountants' role in IT sustainability practice. This finding is also in agreement with some previous studies (Oztekin et al., 2017; Al-Naqbi \& Alshannag, 2018; Junger da Silva et al., 2020b) that found no significant difference on gender group about the perception of students about sustainable development concerns in higher education. The result is different from some previous studies that stated differences in gender perception toward sustainability issues (Xiao \& Hong, 2018; Olsson et al., 2019; Wang et al., 2020). This could be caused by most of the studies that investigate gender influence in sustainability issues are focused on environmentally friendly behavior, and it is different from students' future professions' role in sustainability issues.

The result shows significant perception differences in the year of the study group for accountants' IT responsibilities and IT sustainability practice variable, resulting in junior students are higher than senior students in understanding the importance of the accountants' role in the IT sustainability practice. This study is in line with (Wang et al., 2020) that found differences in sustainability consciousness perception of different students' levels. Junior students are usually still enthusiastic and have high expectations about starting to learn in accounting major, so the IT responsibility, IT 
competence, and their future profession's role in IT sustainability are seen as essential things. While for senior students, even though they relatively have more exposure to IT-related courses, they show less in understanding the importance of the role of accountants in the IT sustainability practice. This result may indicate that either the content or the method of delivering IT-related accounting courses does not match students' expectations or does not motivate enough for senior students, but this warrants further investigation.

The statistically significant difference shown in the university type group refers to different perceptions between students in private universities and public universities regarding the importance of the role of accountants in the IT sustainability practice. This is in line with Wang et al. (2020) that specifically compare the perception of students toward sustainable development in public and private universities in China. They find higher level of perceptions from private university's students compared to public universities is due to active campus sustainability engagement and positive stakeholder relationship managed by university management. In the current study, the result shows inversely that students in public universities have a higher perception than students in private universities toward IT sustainability issues. This may happen because, in Indonesia, private universities do not emphasize enough the understanding of learning about environmental issues. Based on the UI Green Metric, universities in Indonesia that have implemented the green campus concept as the primary goal of educational institutions are mostly public universities, and very few private universities take part (UI Green Metric, 2021). University of Indonesia Green Metric is a ranking of the best universities based on campus environmental management. They measure the sustainability practices in Indonesian universities, such as infrastructure for open spaces, applying renewable energy (solar panels, smart building), implementing paperless, and specific waste treatment (UI Sustainability Report, 2018).

\section{Conclusions}

The majority of accounting students agree with the importance of accountants' role in IT sustainability practices by utilizing information systems. In practical implication, there is a high perception in accounting students that accountants should directly contribute to IT sustainability practice. Students agreed on the importance for accountants to have specific knowledge and skills, such as IT asset management, energy efficiency, and management control systems of IT strategy, in support of accountants' IT responsibility and IT competence. Differences in perceptions are found in the senior and junior student groups, as well as groups of students from public and private universities, while in the gender group, there is no difference in perception. This study can be useful for accounting education providers and teachers in supporting students to understand the practical implementation in accounting professions regarding their role in sustainability through the utilization of information system technology. They may consider brainstorming more effective IT-related course delivery methods to help motivate senior students which they will soon graduate and become professional accountants. This study shows that students in both private and public universities have already seen the importance of their profession's contribution to sustainability issues. Therefore, management in private universities must emphasize more regarding the awareness of environmental issues. The current study is conducted on students to measure the perception of their future profession's role in IT sustainability. Future research could approach from another perspective regarding the perception of professional accountants from different positions and lengths of work on their role in IT sustainability issues.

\section{References}

AACSB International. (2014). AACSB International Accounting Accreditation Standard A7: Information Technology Skills and Knowledge for Accounting Graduates: An Interpretation, (September), 1-9. Retrieved www.aacsb.edu/-/media/aacsb/publications/ white-papers/accounting-accreditationstandard-7.ashx? $1 \mathrm{a}=\mathrm{en}$

AACSB International. (2018). 2018 Standards for Accounting Accreditation.

Adams, C. A., \& Abhayawansa, S. (2021). Connecting the COVID-19 Pandemic, Environmental, Social and Governance (ESG) Investing and Calls for 'Harmonisation' of Sustainability Reporting. Critical Perspectives on Accounting, (xxxx), 102309. doi.org/ 10.1016/j.cpa.2021.102309

Al-Naqbi, A. K., \& Alshannag, Q. (2018). The Status of Education for Sustainable Development and Sustainability Knowledge, Attitudes, 
and Behaviors of UAE University Students. International Journal of Sustainability in Higher Education, 19(3), 566-588. doi.org/ 10.1108/IJSHE-06-2017-0091

Andiola, L. M., Masters, E., \& Norman, C. (2020). Integrating Technology and Data Analytic Skills Into The Accounting Curriculum: Accounting Department Leaders' Experiences and Insights. Journal of Accounting Education, 50(xxxx), 100655. doi.org/10.1016/j.jaccedu.2020.100655

Bebbington, J., Schneider, T., Stevenson, L., \& Fox, A. (2020). Fossil Fuel Reserves and Resources Reporting and Unburnable Carbon: Investigating Conflicting Accounts. Critical Perspectives on Accounting, 66, 102083. https://doi.org/10.1016/j.cpa.2019.04.004

Bose, R., \& Luo, X. (2011). Integrative Framework for Assessing Firms' Potential to Undertake Green IT Initiatives Via Virtualization - A Theoretical Perspective. Journal of Strategic Information Systems, 20(1), 38-54. doi.org/10.1016/j.jsis.2011.01. 003

Bose, R., \& Luo, X. (2012). Green IT adoption: A Process Management Approach. International Journal of Accounting and Information Management, 20(1), 63-77. doi.org/10.1108/ 18347641211201081

Boulianne, E., Keddie, L. S., \& Postaire, M. (2018). (Non) Coverage of Sustainability Within The French Professional Accounting Education Program. Sustainability Accounting, Management and Policy Journal, 9(3), 313-335. doi.org/10.1108/SAMPJ-092017-0119

Brennan, B., Baccala, M., \& Flynn, M. (2017). Artificial Intelligence Comes to Financial Statement Audits. Retrieved December 6, 1BC, from www.cfo.com/auditing/2017/02/ artificial-intelligence-audits/

Ceulemans, K., Molderez, I., \& Van Liedekerke, L. (2015). Sustainability Reporting In Higher Education: A Comprehensive Review of The Recent Literature and Paths for Further Research. Journal of Cleaner Production, 106, 127-143. doi.org/10.1016/j.jclepro.2014.09. 052

Cho, C. H., Senn, J., \& Sobkowiak, M. (2021). Sustainability At Stake During COVID-19: Exploring The Role of Accounting in Addressing Environmental Crises. Critical Perspectives on Accounting, (xxxx), 102327. https://doi.org/10.1016/j.cpa.2021.102327
Damasiotis, V., Trivellas, P., Santouridis, I., Nikolopoulos, S., \& Tsifora, E. (2015). IT Competences for Professional Accountants. A Review. Procedia - Social and Behavioral Sciences, 175, 537-545. doi.org/10.1016/ j.sbspro.2015.01.1234

de Villiers, C., \& Sharma, U. (2020). A Critical Reflection on The Future of Financial, Intellectual Capital, Sustainability and Integrated Reporting. Critical Perspectives on Accounting, 70. https://doi.org/10.1016/j.cpa. 2017.05.003

Deegan, C. (2017). Twenty Five Years of Social and Environmental Accounting Research Within Critical Perspectives of Accounting: Hits, Misses and Ways Forward. Critical Perspectives on Accounting, 43, 65-87. https://doi.org/10.1016/j.cpa.2016.06.005

Dimitrios, N. K., Sakas, D. P., \& Vlachos, D. S. (2013). Analysis of Strategic Leadership Models in Information Technology. Procedia - Social and Behavioral Sciences, 73, 268275. doi.org/10.1016/j.sbspro.2013.02.052

Dzuranin, A. C., Jones, J. R., \& Olvera, R. M. (2018). Infusing Data Analytics Into The Accounting Curriculum: A Framework and Insights From Faculty. Journal of Accounting Education, 43(March), 24-39. https://doi.org/ 10.1016/ j.jaccedu.2018.03.004

Ebaid, I. E.-S. (2021). Sustainability and Accounting Education: Perspectives of Undergraduate Accounting Students in Saudi Arabia. Journal of Applied Research in Higher Education, ahead-of-p(ahead-of-print). doi.org/ 10.1108/jarhe-05-2021-0183

Ernst \& Young, (EY). (2016). How Big Data and Analytics are Transforming the Audit. Retrieved 1BC, from www.ey.com/en_gl/ assurance/how-big-data-and-analytics-aretransforming-the-audit

Harmon, R. R., Demirkan, H., \& Raffo, D. (2012). Roadmapping The Next Wave of Sustainable IT. Foresight, 14(2), 121-138. https://doi.org/ 10.1108/14636681211222401

Jiputra, J.A., Tarigan, Z.J.H., and Siagian, H. (2020). The Effect of Information Technology on Retailer Satisfaction through Supply Chain Management Practices and Retailer-Distributor Relationship in Modern Retailer Surabaya. International Journal of Business Studies, 3(2), 126-134, doi.org/10.9744/ijbs. 3.2.126-134

Journeault, M., Levant, Y., \& Picard, C. F. (2021). Sustainability Performance Reporting: A 
Technocratic Shadowing and Silencing. Critical Perspectives on Accounting, 74(xxxx), 102145. doi.org/10.1016/j.cpa. 2019.102145

Junger da Silva, R., Tommasetti, R., Zaidan Gomes, M., \& da Silva Macedo, M. A. (2020). Accountants' IT Responsibilities and Competencies from A Student Perspective. Higher Education, Skills and Work-Based Learning, 11(2), 471-486. doi.org/10.1108/ HESWBL02-2020-0028

Junger da Silva, R., Tommasetti, R., Zaidan Gomes, M., \& da Silva Macedo, M. Á. (2020). How Green is Accounting? Brazilian Students' Perception. International Journal of Sustainability in Higher Education, 21(2). https://doi.org/10.1108/IJSHE-07-2019-0232

Khan, H. Z., Bose, S., \& Johns, R. (2020). Regulatory Influences on CSR Practices Within Banks in An Emerging Economy: Do Banks Merely Comply? Critical Perspectives on Accounting, 71(xxxx), 102096. doi.org/ 10.1016/j.cpa.2019.102096

Kiddee, P., Naidu, R., \& Wong, M. H. (2013). Electronic Waste Management Approaches: An Overview. Waste Management, 33(5), 1237-1250. doi.org/10.1016/j.wasman.2013. 01.006

Kokina, J., \& Davenport, T. H. (2017). The Emergence of Artificial Intelligence: How Automation is Changing Auditing. Journal of Emerging Technologies in Accounting, 14(1), 115-122. https://doi.org/10.2308/jeta-51730

KPMG. (2020). The Time has Come: The KPMG Survey of Sustainability Reporting 2020. Kpmg Impact.

Kruskopf, S., Lobbas, C., Meinander, H., Söderling, K., Martikainen, M., \& Lehner, O. (2020). Digital Accounting and The Human Factor: Theory and Practice. ACRN Journal of Finance and Risk Perspectives, 9(1), 78-89. https://doi.org/10.35944/JOFRP.2020.9.1.006

Makarenko, I., \& Plastun, A. (2017). The Role of Accounting in Sustainable Development. Accounting and Financial Control, 1(2), 4-12. https://doi.org/10.21511/afc.01(2).2017.01

Merhout, J. W., Callison, M. M., \& Schiller, S. (2016). Environmental Management Information Systems: A Conceptual Overview and Review of Vendors. Retrieved from aisel.aisnet.org/mwais2016\%0Ahttp://aisel.ais net.org/mwais2016/6\%0Ahttp://aisel.aisnet.or g/mwais2016\%0Ahttp://aisel.aisnet.org/mwai s2016/6
Müller-Christ, G., Sterling, S., Van Dam-Mieras, R., Adomßent, M., Fischer, D., \& Rieckmann, M. (2014). The Role of Campus, Curriculum, and Community in Higher Education for Sustainable Development - A Conference Report. Journal of Cleaner Production, 62, 134-137. doi.org/10.1016/j.jclepro.2013.02.029

Olsson, D., Gericke, N., Boeve-de Pauw, J., Berglund, T., \& Chang, T. (2019). Green schools in Taiwan-Effects on student sustainability consciousness. Global Environmental Change, 54(March 2018), 184-194. doi.org/ 10.1016/j.gloenvcha. 2018.11.011

Oztekin, C., Teksöz, G., Pamuk, S., Sahin, E., \& Kilic, D. S. (2017). Gender Perspective on The Factors Predicting Recycling Behavior: Implications from The Theory of Planned Behavior. Waste Management, 62, 290-302. https://doi.org/10.1016/j.wasman.2016.12.036

Parawiyati, Soejipto, B. E., \& Wahyono, H. (2014). Perceptions of Academics and Practitioners against Social Responsibility Accounting Learning in Higher Education, 5(24), 128-139.

Rene, E. R., Sethurajan, M., Kumar Ponnusamy, V., Kumar, G., Bao Dung, T. N., Brindhadevi, K., \& Pugazhendhi, A. (2021). Electronic Waste Generation, Recycling and Resource Recovery: Technological Perspectives and Trends. Journal of Hazardous Materials, 416 (February), 125664. doi.org/10.1016/j.jhazmat 2021.125664

Richardson, V. J., \& Shan, Y. (2019). Data Analytics in The Accounting Curriculum. Advances in Accounting Education: Teaching and Curriculum Innovations, 23, 67-79. https://doi.org/10.1108/S1085462220190000023004

Rosmida, R. (2019). Transformasi Peran Akuntan dalam Era Revolusi Industri 4.0 dan Tantangan Era Society 5.0. Inovbiz: Jurnal Inovasi Bisnis, 7(2), 206. doi.org/10.35314/inovbiz.v7i2.1197

Rounaghi, M. M. (2019). Economic Analysis of Using Green Accounting and Environmental Accounting to Identify Environmental Costs and Sustainability Indicators. International Journal of Ethics and Systems, 35(4), 504512. doi.org/10.1108/IJOES-03-2019-0056

She, C., \& Michelon, G. (2019). Managing Stakeholder Perceptions: Organized Hypocrisy in CSR disclosures on Facebook. Critical Perspectives on Accounting, 61, 54-76. doi.org/10.1016/j.cpa.2018.09.004 
Sledgianowski, D., Gomaa, M., \& Tan, C. (2017). Toward Integration of Big Data, Technology and Information Systems Competencies Into The Accounting Curriculum. Journal of Accounting Education, 38, 81-93.

Soetanto, T.V., Proboyo, A., and Putri, P.A. (2020). The Indirect Effect of Computer SelfEfficacy of E-Commerce Users on Intention to Use. International Journal of Business Studies, 3(2), 75-85, doi.org/10.9744/ijbs.3.2. 75-85

Tandiontong, M., Sinuraya, C., and Rajagukguk, S.M. (2019). The Influence of Auditor's Education Level, Accounting Education, Public Accountant Firm Size on Accounting Profession: Implication to Good Corporate Governance in Indonesia. International Journal of Business Studies, 2 (1), 1-7, doi.org/ 10.9744/ijbs.2.1.1-7

UI Green Metric. (2021). University of Indonesia. Retrieved from greenmetric.ui.ac.id/rankings/ ranking-by-country-2020/Indonesia

UI Sustainability Report. (2018). University of Indonesia Sustainability Report 2018.

UNCTAD. (2011). Model Accounting Curriculum (Revised), 123. Retrieved unctad.org/en/PublicationsLibrary/diaemisc20 11d1_en.pdf

UNESCO. (2017). Education for Sustainable Development Goals Learning Objectives (Note: Imp lementierung der BNE).
Vicente-Molina, M. A., Fernández-Sainz, A., \& Izagirre-Olaizola, J. (2018). Does Gender Make A Difference in Pro-Environmental Behavior? The Case of The Basque Country University Students. Journal of Cleaner Production, 176, 89-98. doi.org/10.1016/ j.jclepro.2017.12.079

Wang, J., Yang, M., \& Maresova, P. (2020). Sustainable Development at Higher Education in China: A Comparative Study of Students' Perception in Public and Private Universities. Sustainability (Switzerland), 12(6). doi.org/ 10.3390/su12062158

Wessels, P. L. (2005). Critical Information and Communication Technology (ICT) Skills for Professional Accountants. Meditari Accountancy Research, 13(1), 87-103. doi.org/10.1108/10222529200500006

Wyness, L., \& Dalton, F. (2018). The Value of Problem-Based Learning in Learning for Sustainability: Undergraduate Accounting Student Perspectives. Journal of Accounting Education, 45 (August 2017), 1-19. doi.org/ 10.1016/j.jaccedu.2018.09.001

Xiao, C., \& Hong, D. (2018). Gender Differences in Environmental Behaviors Among the Chinese Public: Model of Mediation and Moderation. Environment and Behavior, 50 (9), 975-996. doi.org/10.1177/001391651772 3126 